\title{
Factors and Features Influencing Laptop Users of Kathmandu, Nepal
}

\author{
Anjay Kumar Mishra*, \& P. S. Aithal** \\ *Post Doctoral Research Scholar, Srinivas University, India and Associate Professor, Madan \\ Bhandari Memorial Academy Nepal, Urlabari3, Morang, Nepal \\ OrcidID: 0000-0003-2803-4918; Email: anjaymishra2000@gmail.com \\ ***Professor, College of Management \& Commerce, Srinivas University, Mangalore, India \\ OrcidID: 0000-0002-4691-8736; E-mail: psaithal@gmail.com
}

Area of the Paper: Business Management.

Type of the Paper: Descriptive Research.

Type of Review: Peer Reviewed as per $|\mathrm{C}| \mathrm{O}|\mathrm{P}| \mathrm{E} \mid$ guidance.

Indexed In: OpenAIRE.

DOI: $\underline{\text { http://doi.org/10.5281/zenodo.4940049 }}$

Google Scholar Citation: IJCSBE

\section{How to Cite this Paper:}

Mishra, Anjay Kumar, \& Aithal, P. S. (2021). Factors and Features Influencing Laptop Users of Kathmandu, Nepal. International Journal of Case Studies in Business, IT, and Education (IJCSBE), 5(1), 132-142. DOI: http://doi.org/10.5281/zenodo.4940049.

International Journal of Case Studies in Business, IT and Education (IJCSBE)

A Refereed International Journal of Srinivas University, India.

Crossref DOI : https://doi.org/10.47992/IJCSBE.2581.6942.0105

(C) With Authors.

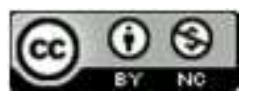

This work is licensed under a Creative Commons Attribution Non-Commercial 4.0 International License subject to proper citation to the publication source of the work.

Disclaimer: The scholarly papers as reviewed and published by the Srinivas Publications (S.P.), India are the views and opinions of their respective authors and are not the views or opinions of the S.P. The S.P. disclaims of any harm or loss caused due to the published content to any party. 


\title{
Factors and Features Influencing Laptop Users of Kathmandu, Nepal
}

\author{
Anjay Kumar Mishra*, \& P. S. Aithal** \\ *Post Doctoral Research Scholar, Srinivas University, India and Associate Professor, Madan \\ Bhandari Memorial Academy Nepal, Urlabari3, Morang, Nepal \\ OrcidID: 0000-0003-2803-4918; Email: anjaymishra2000@gmail.com \\ ***Professor, College of Management \& Commerce, Srinivas University, Mangalore, India \\ OrcidID: 0000-0002-4691-8736; E-mail: psaithal@ gmail.com
}

\begin{abstract}
Purpose: Consumer perception of laptop users is a great concern for market analysts, user and sellers. The aim is to assess the important factors and major media of advertisements influencing the purchase decision of a particular laptop brand using descriptive statics.

Design/Methodology/Approach: The study is based on scheduled survey of 120 laptop users. Cross tabulation, percentage, and Likert scale were used to describe the perception quantitatively.

Findings/Result: The study also showed that people are less price sensitive, people hardly switch from one brand of laptop to another because of price. In case of unavailability of their most preferred brand of laptop, most of them wait for their preferred brand, and only few buys second preferred brand or any available brand. Only higher price doesn't mean good quality to most of the costumers and they are also not comfortable in using the recent, not proven technology. Customers are also influenced by sales schemes and offer while purchasing laptop. Focuses on 15-45 years user group should be targeted.

Originality/Value: It is survey research significant for laptop buyers and sellers of Nepal using the descriptive model.
\end{abstract}

Paper Type: Descriptive survey research

Keywords: features, descriptive stat, price, advertise, market shortage

\section{INTRODUCTION :}

Marketing is all about giving evidence and confidence in a product or service by the seller to the buyer through cost-effectiveness and quality assurance to conformance of requirements with competitive advantages. Prof. Kotler [1] defines "a product as anything that can be offered to a market to satisfy a want or need." A product is made to be known through its brand name and its sellers' main job to make buyers remember the name in a positive way to create brand loyalty. Nepal agriculture country its specific consumer characteristics are unique as brand loyalty is high, does not consider time and cost tradeoff, consider friend and enemy to the seller, attracted by small things, hide weakness regarding the ability to purchase and blame others. A study conducted by Sah and Mishra [2] regarding the laptop demand of Kathmandu valley also shows the demand of different brands varies with different factors. The research will focus on analyzing the consumers' brand preference and identifying various factors which enable a customer to prefer a particular brand of Laptop. Every organization wants to successfully market their product and desire for a greater extent of customer attraction and have strong customer loyalty towards their products. In this era of aggressive competition, successful marketing of its products requires a clear understanding of consumer's needs, wants, preferences, etc.

This study basically focuses on the preferred brand of laptops by general consumers of Kathmandu valley. It deals with analyzing the various aspects of the brand that affect the consumer's behavior and their decision making. This study also tries to gather information regarding the consumer's decision to purchase a particular brand of laptop and what features and attributes of the product made them to choose a particular brand. It also tries to analyze the other external factors that affect the consumer's 
decision making process.

\section{OBJECTIVES :}

The paper aims to identify the important factors and major media of advertisements influencing purchase decisions of a particular laptop brand using descriptive statics.

\section{LITERATURE REVIEW :}

\subsection{Conceptual Framework:}

Liking and disliking which determines preference depends upon different demographic factors such as Age, Gender, Income, Educational Qualification, Marital Status, Occupation, Advertisement, and Friend and family influence (Mishra, 2019) [3]. A detailed study of it might be helpful for professional marketers to accurately assess what is the exact need of the customer. Intended function, Features, Reliability, Maintainability, durability and performance of different level might be expected by different customers should be addressed by Design of Experiments to make product usable as influencing strategy (Mishra and Sharestha, 2019) [4]. For example, students who are 18 to 25 years and are very fond of playing games would want to have a graphics card in their laptop so that they can play high resolution games. But the persons who are around 30 to 40 years old needs laptop for their official work so they really don't bother about the graphics card. She shops more frequently compared to male so they bargain more than males. Female often tend to compare the price, quality, services between the brands whereas male are more brand loyal. Educational Qualification: Since Laptop is high involvement product. Consumer search information regarding Laptop either by visiting different outlet or online through internet surfing. Consumer then uses various collected information to evaluate the available alternatives. People with the higher educational backgrounds may use complex information to compare various brands available in the market before making a purchase decision. So educational qualification may also affect the brand that consumer purchase.

Marital Status: Marital status of people is another independent variable taken into consideration for research, it may also affect the brand that consumer purchase. The consumers are involved in various professions holds a certain role to play in their profession and they purchase the goods which support in fulfilling their specific roles. For example, a businessman would like to purchase a Laptop that supports his inventory management software. Whereas engineering students would want to purchase a laptop that supports high resolution graphics and designing software.

\subsection{Creating Brand Preference:}

As an example of the use of branding strategies in agribusiness, we may mention the stamp 'Pampa Gacuho', created by a nonprofit organization that brings together producers, industry, retail, and other agents of the productive chain of beef cattle. This organization has as its main goal the preservation and protection of geographical indication of meat, leather, and its derivatives, produced in the southern region of Brazil known as "Pampa Gaúcho da Campanha Meridional" (APROPAMPA, 2011) [5]. This success case shows the need for brand creating. Brand loyalty varies across consumers as well as products and is relatively high in the products that are frequently needed than those that are needed or used less frequently. The consumers belonging to the age group of 26 to 40 years are more brand loyal than those belonging to any other age group. The consumer belonging to the nuclear family system is comparatively more brand loyal than those to the joint family system. Brand loyalty is strongly associated with consumers' income and shop loyalty and brand loyal consumer is less influenced by special deals like free samples; discount coupons, price activities, and advertisement. In the case of Kathmandu, a Mobile adoption study has been conducted and branding effect found high impact [6]. This shows emotional connection might be the cause of brand creation. For creating brand preference, Awareness, emotional connection, differentiation, accessibility, and value can be used as shown in figure1 for creating their success story. 




Fig. 1: Creating brand preference

\section{RESEARCH METHODOLOGY:}

It is a descriptive statistics based survey research for laptop brand preferences in the case of Kathmandu valley of the capital city of Nepal

\subsection{Population and Sample size}

Based on available laptop users 120 Laptop users were respected as respondents based on convenience from the quota to get the objective. The respondents include people within Kathmandu Valley and were students or people involved in a different occupation. The people selected for this study were 16 years and above.

\subsection{Data Collection}

The data collection method used was the Survey Method. The respondents filled out the structured questionnaire following the instructions given in the questions. The questionnaires were filled in the presence of researcher and collected immediately.

\subsection{Data Analysis Tools}

All the distributed questionnaires were collected and analyzed. As the nature of the study is confined to a particular area, some statistical and descriptive tools are used. Since the study is based on quantitative data, mainly the descriptive analysis has been made to draw some conclusions of the study e.g., Percentage.

The Likert scale has been used for the perception study of selected variables.

\section{RESULTS AND DISCUSSION :}

\subsection{Responsiveness of Factors of Brand Preferred :}

The brand preference has been analyzed based on selected variables as the variables affect the strategy (Heryanto, H. 2011) [7].

\subsubsection{Gender responsiveness for a preferred brand of Laptop:}


Table 1: Gender and most preferred brand of Laptop

\begin{tabular}{|l|l|l|l|}
\hline \multicolumn{4}{|c|}{ Most Preferred Laptop Brand $*$ Gender Cross tabulation } \\
\hline $\begin{array}{l}\text { Most Preferred Laptop } \\
\text { Brand }\end{array}$ & Gale & Female & Total \\
\hline Dell & 30 & 15 & 45 \\
\hline Apple & 33 & 9 & 42 \\
\hline Lenovo & 6 & 4 & 10 \\
\hline Sony & 6 & 2 & 8 \\
\hline HP/Compaq & 6 & 1 & 7 \\
\hline Acer & 5 & 1 & 6 \\
\hline ASUS & 1 & 0 & 1 \\
\hline Toshiba & 1 & 0 & 1 \\
\hline Total & 88 & 32 & 120 \\
\hline
\end{tabular}

Table 1 shows the cross tabulation of most preferred brand of laptop and gender. It shows that Apple is most preferred brand among and Dell is second most preferred brand among males. Among females it is just reverse, Dell is most preferred brand and Apple is second most preferred brand of Laptop. Kotler, P. (2013) also advised to analyze gender effect for marketing planning.

5.1.2 Marital status responsiveness preferred brand of Laptop:

Table 2 : Marital status and most preferred brand of Laptop

\begin{tabular}{|l|l|l|l|}
\hline \multicolumn{4}{|l|}{ Most Preferred Laptop Brand * Marital Status Cross tabulation } \\
\hline & \multicolumn{1}{|l|}{ Marital Status } & Total \\
\hline Most Preferred Laptop Brand & Married & Unmarried & \\
\hline Dell & 23 & 22 & 45 \\
\hline Apple & 19 & 23 & 42 \\
\hline Lenovo & 7 & 3 & 10 \\
\hline Sony & 1 & 7 & 8 \\
\hline HP/Compaq & 1 & 6 & 7 \\
\hline Acer & 2 & 4 & 6 \\
\hline Toshiba & 0 & 1 & 1 \\
\hline ASUS & 0 & 1 & 1 \\
\hline Total & 53 & 67 & 120 \\
\hline
\end{tabular}

Above table 2 shows the cross tabulation between most preferred brand of laptop and marital status. It shows that among married people Dell is the most preferred brand and apple is second most preferred brand. Whereas among unmarried people Apple is most preferred brand and Dell is second most preferred brand.

\subsubsection{Implication of Age on brand selection}

Table 3 : Implication of Age on brand

\begin{tabular}{|c|c|c|c|c|}
\hline \multicolumn{5}{|c|}{ Most Preferred Laptop Brand * Age Cross tabulation } \\
\hline \multirow[t]{2}{*}{$\begin{array}{lll}\text { Most } & \text { Preferred } & \text { Laptop } \\
\text { Brand } & & \\
\end{array}$} & \multicolumn{3}{|c|}{ Age Group } & \multirow[t]{2}{*}{ Total } \\
\hline & $15-30$ & $30-45$ & $45-60$ & \\
\hline Dell & 25 & 19 & 1 & 45 \\
\hline Apple & 28 & 11 & 3 & 42 \\
\hline Lenovo & 6 & 1 & 3 & 10 \\
\hline
\end{tabular}




\begin{tabular}{|l|l|l|l|l|} 
Sony & 7 & 1 & 0 & 8 \\
\hline HP/Compaq & 7 & 0 & 0 & 7 \\
\hline Acer & 6 & 0 & 0 & 6 \\
\hline Toshiba & 1 & 0 & 0 & 1 \\
\hline ASUS & 1 & 0 & 0 & 1 \\
\hline Total & 81 & 32 & 7 & 120 \\
\hline
\end{tabular}

Above table 3 shows that, the most preferred brand among age group 15-30 years is Apple and second most preferred brand is Dell. Among 30-45 years age group Dell is most preferred brand and Apple is second most preferred brand of laptop. And among 45-60 years age group Lenovo and Apple are most preferred brand and Dell is second most preferred brand of laptop.

\subsubsection{Occupational Responsiveness on brand preference}

Table 4 : Current occupation and most preferred brand of Laptop

\begin{tabular}{|l|l|l|l|l|l|}
\hline Most Preferred Laptop Brand * Current Occupation Cross tabulation \\
\hline & \multicolumn{4}{l|}{ Current Occupation } & Total \\
\hline $\begin{array}{l}\text { Most Preferred } \\
\text { Laptop Brand }\end{array}$ & Student & $\begin{array}{l}\text { Business } \\
\text { Person }\end{array}$ & $\begin{array}{l}\text { Government } \\
\text { Employee }\end{array}$ & $\begin{array}{l}\text { Private working } \\
\text { Professional }\end{array}$ & \\
\hline Dell & 10 & 5 & 14 & 16 & 45 \\
\hline Apple & 8 & 13 & 13 & 8 & 42 \\
\hline Lenovo & 1 & 6 & 2 & 1 & 10 \\
\hline Sony & 2 & 3 & 0 & 3 & 8 \\
\hline HP/Compaq & 5 & 2 & 0 & 0 & 7 \\
\hline Acer & 2 & 1 & 1 & 2 & 6 \\
\hline Toshiba & 1 & 0 & 0 & 0 & 1 \\
\hline ASUS & 1 & 0 & 0 & 0 & 1 \\
\hline Total & 30 & 30 & 30 & 30 & 120 \\
\hline
\end{tabular}

Table 4 shows the cross tabulation between most preferred brand of laptop and current occupation. Among students Dell is most preferred brand of Laptop, followed by Apple. Business person mostly prefer Apple and secondly Lenovo. Dell is most preferred brand and Apple is second most preferred among government employee and private working professionals. According to Kotler, P., \& Armstrong, G. (2010), Educational qualification should be considered for deciding purchasing behavior of consumer.

\subsubsection{Educational qualification Responsiveness on brand preference}

Table 5 : Educational Qualification for Brand Selection

\begin{tabular}{|l|l|l|l|l|l|}
\hline Most Preferred Laptop Brand * Educational Qualification Cross tabulation \\
\hline & \multicolumn{6}{|l|}{ Educational Qualification } & Total \\
\hline Most Preferred Laptop Brand & $\begin{array}{l}\text { Below } \\
\text { SLC }\end{array}$ & $10+2$ & $\begin{array}{l}\text { Bachelors } \\
\text { Degree }\end{array}$ & $\begin{array}{l}\text { Masters Degree \& } \\
\text { Above }\end{array}$ & \\
\hline Dell & 1 & 5 & 21 & 18 & 45 \\
\hline Apple & 0 & 8 & 12 & 22 & 42 \\
\hline Lenovo & 0 & 3 & 4 & 3 & 10 \\
\hline Sony & 0 & 1 & 5 & 2 & 8 \\
\hline HP/Compaq & 0 & 4 & 3 & 0 & 7 \\
\hline Acer & 0 & 0 & 5 & 1 & 6 \\
\hline Toshiba & 0 & 0 & 1 & 0 & 1 \\
\hline ASUS & 1 & 0 & 0 & 0 & 1 \\
\hline
\end{tabular}




$21 \quad 51$

46

Table 5 shows the cross tabulation between educational qualification and most preferred brand of laptop. Apple is considered as the most preferred brand of laptop by the people those who have qualified masters degree and above and Dell is their second most preferred brand. Among the people those who have completed bachelors degree, Dell is most preferred brand and Apple is second most preferred brand. Among the 10+2 qualified people Apple is the most preferred brand and Dell is second most preferred brand.

\subsubsection{Effects of Income on brand of Laptop}

Table 6: Monthly income and most preferred brand of Laptop

\begin{tabular}{|l|l|l|l|l|l|}
\hline \multicolumn{2}{|l|}{ Most Preferred Laptop Brand Monthly Income Cross tabulation } \\
\hline & \multicolumn{2}{l}{ Monthly Income } & Total \\
\hline $\begin{array}{l}\text { Most Preferred Laptop } \\
\text { Brand }\end{array}$ & Below 25000 & $25000-50000$ & $\begin{array}{l}50000- \\
100000\end{array}$ & $\begin{array}{l}\text { Above } \\
100000\end{array}$ & \\
\hline Dell & 25 & 17 & 3 & 0 & 45 \\
\hline Apple & 13 & 19 & 9 & 1 & 42 \\
\hline Lenovo & 1 & 5 & 2 & 2 & 10 \\
\hline Sony & 5 & 2 & 1 & 0 & 8 \\
\hline HP/Compaq & 6 & 1 & 0 & 0 & 7 \\
\hline Acer & 4 & 1 & 1 & 0 & 6 \\
\hline Toshiba & 1 & 0 & 0 & 0 & 1 \\
\hline ASUS & 1 & 0 & 0 & 0 & 1 \\
\hline Total & 56 & 45 & 16 & 3 & 120 \\
\hline
\end{tabular}

Consumer with monthly income less than 25 thousand, Dell is the most preferred brand and Apple is second most preferred brand. Among those whose monthly income is between 25 to 50 thousand and 50 thousand to 1 lakh, Apple is the most preferred brand and Dell is second most preferred brand of laptop. Lenovo is most preferred brand of Laptop among the people those who monthly earns above 1 lakh.

\subsubsection{Willingness to pay for most preferred brand of Laptop}

Table 7 : Willingness to pay for Laptop and most preferred brand of Laptop

\begin{tabular}{|l|l|l|l|l|}
\hline \multicolumn{5}{|l|}{ Most Preferred Laptop Brand * Pay for Laptop Cross tabulation } \\
\hline $\begin{array}{l}\text { Most Preferred Laptop } \\
\text { Brand }\end{array}$ & $\begin{array}{l}\text { Less than } \\
50000\end{array}$ & $50000-100000$ & $\begin{array}{l}\text { Above } \\
100000\end{array}$ & Total \\
\hline Dell & 21 & 24 & 0 & 45 \\
\hline Apple & 9 & 28 & 5 & 42 \\
\hline Lenovo & 1 & 9 & 0 & 10 \\
\hline Sony & 3 & 5 & 0 & 8 \\
\hline HP/Compaq & 0 & 6 & 1 & 7 \\
\hline Acer & 1 & 5 & 0 & 6 \\
\hline Toshiba & 0 & 1 & 0 & 1 \\
\hline ASUS & 0 & 1 & 0 & 1 \\
\hline Total & 35 & 79 & 6 & 120 \\
\hline
\end{tabular}

Table 7 shows the cross tabulation between most preferred brand of Laptop and willingness to pay for a laptop. It shows that, Dell is the most preferred brand among those who want to pay below 50 thousand 
followed by Apple. Among the respondents who want to pay between 50 thousand to $1 \mathrm{Lakh}$, Apple is most preferred brand followed by Dell. And also, among the respondent's group who want to pay above 1 Lakh, Apple is the most preferred brand of laptop.

5.1.8 Purchasing Decision during shortage of first choice Brand of Laptop

Table 8 : Purchasing decision during shortage of preferred Brand

\begin{tabular}{|l|l|l|l|l|}
\hline \multicolumn{4}{|l|}{ Most Preferred Laptop Brand * Preferred brand not available Cross tabulation } \\
\hline Most Preferred Laptop Brand brand not available & $\begin{array}{l}\text { Buy second } \\
\text { preferred brand }\end{array}$ & $\begin{array}{l}\text { Buy any } \\
\text { available }\end{array}$ & Total \\
\hline preferred brand & 23 & 14 & 5 & 42 \\
\hline Dell & 18 & 20 & 7 & 45 \\
\hline Lenovo & 7 & 2 & 1 & 10 \\
\hline HP/Compaq & 4 & 3 & 0 & 7 \\
\hline Sony & 4 & 4 & 0 & 8 \\
\hline Toshiba & 1 & 0 & 0 & 1 \\
\hline Acer & 1 & 3 & 2 & 6 \\
\hline ASUS & 1 & 0 & 0 & 1 \\
\hline Total & 59 & 46 & 15 & 120 \\
\hline
\end{tabular}

Above table 8 shows the cross tabulation between most preferred brand of laptop and purchasing decision of respondents in unavailability of most preferred brand of laptop. It shows that Apple users are most brands conscious. Out of 42 Apple users 23 says that they would wait for the preferred brand of Laptop, 14 says that they would buy second preferred brand and only 5 respondents says that they would buy any available brand. Secondly Dell users are most brands conscious. Out of 45 respondents 18 says that they would wait for preferred brand of laptop, 20 respondents says that they would buy second preferred brand and only 7 will buy any available brand. Lenovo users are also brand conscious; out of 10 respondents, 7 says that they would wait for the preferred brand of laptop, 2 says they would buy second preferred brand and only 1 would buy any available brand.

\subsection{1: Perception regarding Influencing Factors}

Table 9: Responses regarding influencing factors

\begin{tabular}{|l|l|l|l|l|l|l|}
\hline \multicolumn{1}{|c|}{ Factors } & \multicolumn{1}{|c|}{$\begin{array}{l}\text { Strongly } \\
\text { disagree }\end{array}$} & Disagree & Neutral & Agree & \multicolumn{1}{c|}{$\begin{array}{c}\text { Strongly } \\
\text { agree }\end{array}$} & Total \\
\hline $\begin{array}{l}\text { Laptop schemes } \\
\text { and offer }\end{array}$ & $2(1.67 \%)$ & $8(6.67 \%)$ & $38(31.67 \%)$ & $59(49.17 \%)$ & $13(10.83 \%)$ & $120(100 \%)$ \\
\hline Advertising Role & $6(5.00 \%)$ & $4(3.33 \%)$ & $32(26.67 \%)$ & $54(45.00 \%)$ & $24(20.00 \%)$ & $120(100 \%)$ \\
\hline $\begin{array}{l}\text { Friend and Family } \\
\text { Influence }\end{array}$ & $2(1.67 \%)$ & $11(9.17 \%)$ & $35(29.17 \%)$ & $58(48.33 \%)$ & $14(11.67 \%)$ & $120(100 \%)$ \\
\hline $\begin{array}{l}\text { Switch brand } \\
\text { because of price }\end{array}$ & $20(16.67 \%)$ & $34(28.33 \%)$ & $41(34.17 \%)$ & $15(12.50 \%)$ & $10(8.33 \%)$ & $120(100 \%)$ \\
\hline $\begin{array}{l}\text { laptop price and } \\
\text { quality }\end{array}$ & $14(11.67 \%)$ & $21(17.50 \%)$ & $36(30 \%)$ & $36(30 \%)$ & $13(10.83 \%)$ & $120(100 \%)$ \\
\hline $\begin{array}{l}\text { Laptop Recent } \\
\text { Technology }\end{array}$ & $12(10 \%)$ & $38(31.67 \%)$ & $33(27.5 \%)$ & $31(25.83 \%)$ & $6(5 \%)$ & $120(100 \%)$ \\
\hline $\begin{array}{l}\text { Laptop brand as a } \\
\text { style statement }\end{array}$ & $14(11.67 \%)$ & $25(20.83 \%)$ & $39(32.50 \%)$ & $33(27.50 \%)$ & $9(7.50 \%)$ & $120(100 \%)$ \\
\hline $\begin{array}{l}\text { Add-on software } \\
\text { packages with } \\
\text { laptops }\end{array}$ & $3(2.50 \%)$ & $7(5.83 \%)$ & $14(11.67 \%)$ & $60(50.00 \%)$ & $36(30 \%)$ & $120(100 \%)$ \\
\hline $\begin{array}{l}\text { Extended service } \\
\text { warranty and after } \\
\text { sales service }\end{array}$ & $3(2.50 \%)$ & $6(5.00 \%)$ & $21(17.50 \%)$ & $39(32.50 \%)$ & $51(42.50 \%)$ & $120(100 \%)$ \\
\hline
\end{tabular}


Table 9 shows that consumers agree or disagree on purchasing decision and schemes and offers provided by various brands of laptop. Out of 120 respondents, $49.17 \%$ agree that the Laptop sales schemes and offers highly influence their purchasing decision. $31.67 \%$ are neutral and $10.83 \%$ strongly agrees. So, to boost up the sales of Laptop manufacturer and distributers should come up with innovative sales promotion, schemes and offers. Out of 120 respondents $45 \%$ agrees that advertisement highly influence their purchasing decision. 26.67\% of respondents are neutral about it and $20 \%$ of the respondents highly agree it. So, while purchasing Laptop consumers are influenced by the advertisement, manufacturer and distributer should advertise their products and services through various advertising medium. Similarly, people perception about role of family and friends while purchasing a laptop, $48.33 \%$ agrees that their purchasing decision of buying a particular brand of laptop is highly influenced by their family and friends. $29.17 \%$ of respondents are neutral and $11.67 \%$ of respondents strongly agreed on this fact. So overall we may say that family and friends play strong role in influencing consumer to buy a particular brand of laptop. The price sensitivity of consumer while purchasing Laptop means switching brands due to price. It shows that does consumer switch from one brand to other because of price. Among 120 respondents $34.17 \%$ are neutral, $28.33 \%$ disagree this statement and $16.67 \%$ strongly disagree it. So, we may say that people are fewer prices sensitive while purchasing a laptop. Among 120 respondents, 30\% of the respondents have neutral response regarding, higher price means good quality. 30\% respondents agree with the statement. $10.83 \%$ strongly agrees and $17.50 \%$ disagree with the statement that higher price means good quality. What people think about recent or not proven technology? Among 120 respondents, $31.67 \%$ of the respondents disagrees or don't like buying products on recent (not-proven technology) and $10 \%$ respondents strongly disagrees it. $25.83 \%$ respondents have neutral response. $25.83 \%$ agrees or don't mind buying products on recent technology and 5\% strongly agree it. The responses about the statement, "I use my laptop brand to make style statement." Among 120 respondents, 32.5\% are neutral. 27.5\% agrees with the statement and 7.5\% strongly agrees it. $20.83 \%$ disagrees with the statement and 11.67 strongly disagrees it. The responses regarding the add-on software package with laptop. Among 120 respondents 50\% agrees that add-on software packages with laptops are most, 30\% strongly agrees it. $11.67 \%$ are neutral, 5.83\% disagree it and only $2.5 \%$ strongly disagrees it. So, laptop manufacturer and distributer should provide add-on software packages with laptop to increase their sales. The respondent's opinion regarding the influence of extended service warranty and after sales service while purchasing a laptop. Among 120 respondents, $42.5 \%$ strongly agrees and $32.5 \%$ agrees that extended service warranty and after sales service highly influence them to buy a particular brand of laptop. $17.5 \%$ have neutral response, $5 \%$ disagrees and $2.5 \%$ strongly disagrees that extended service warranty and after sales service highly influence them to buy a particular brand of laptop. Even Kotler, P., \& Keller, K. L. (2011) focuses on similar aspects for strategy formulation.

\subsubsection{Perception on Brand preference of Laptop on the basis of various factors}

Table 10. Brand preference of Laptop on the basis of various features

\begin{tabular}{|l|l|l|l|l|l|}
\hline Descriptive Statistics & Item No. & $\mathrm{N}$ & Mean & $\%$ & $\begin{array}{l}\text { Std. } \\
\text { Deviation }\end{array}$ \\
\hline Features & Item 1 & 120 & 3.92 & $78.3 \%$ & 0.88 \\
\hline Video Quality & Item 2 & 120 & 3.90 & $78.0 \%$ & 0.98 \\
\hline Brand Image & Item 3 & 120 & 3.84 & $76.8 \%$ & 0.98 \\
\hline Style & Item 4 & 120 & 3.78 & $75.5 \%$ & 0.97 \\
\hline Configuration & Item 5 & 120 & 3.76 & $75.2 \%$ & 0.91 \\
\hline Audio Quality & Item 6 & 120 & 3.60 & $72.0 \%$ & 1.06 \\
\hline Price & Item 7 & 120 & 3.58 & $71.5 \%$ & 0.89 \\
\hline Convenience of service & Item 8 & 120 & 3.52 & $70.3 \%$ & 1.17 \\
\hline Laptop Attributes Average Score & 120 & 3.74 & $74.7 \%$ & 0.98 \\
\hline
\end{tabular}

Cronbach's Alpha 0.863

In order to assess factors that affect the brand preference of laptops among consumers in Kathmandu 
valley, 8 items were identified from the questionnaire and score on the responses of the sampled respondents has been calculated. Mean, percentage, and Standard deviation have been presented in table 14. It has been found that the overall mean score for all 120 items put together is 3.74 (percentage score $74.7 \%$ ) on 5-point scale. Thereby it can be stated that the overall factors affecting the brand preference of Laptop are at a satisfactory level or above average.

The most important factor that people highly consider while purchasing a laptop is a feature, which scores 3.92 on 5-point scale (percentage score 78.3). Video quality and Audio scores are 3.90 (percentage score 78) and 3.84 (percentage score 76.8) respectively, which are above average. Brand Image, Style, and configuration scores are 3.84 (percentage score 76.8), 3.78 (percentage score 75.5), and 3.76 (percentage score 75.2) respectively, they are also scored above average. The factors that are considered least are Price and convenience of service, their scores are 3.58 (percentage score 71.5) and 3.52 (percentage score 70.3) respectively on 5-point scale.

\section{CONCLUSION :}

With the emergence of different brands, the purchase of laptops has become quite easy these days. The ability of people to purchase has increased vastly. With the availability of a variety of brands in the market and intense competition between them, every seller tries their best to sell their products by adopting various marketing tactics. One way is selling the product at a lower price than that of the competitors which might be ineffective. Hence, these days, the price of laptop sets has reduced considerably making it affordable by almost everyone. The study showed that the consumer's preference of a brand is reflected mainly by features, audio quality and video quality. The most important factor that people highly consider while purchasing a laptop is a feature, which scores 3.92 on 5-point scale (percentage score 78.3). Video quality and Audio scores are 3.90 (percentage score 78) and 3.84 (percentage score 76.8) respectively, which are above average. Brand Image, Style and configuration scores are 3.84 (percentage score 76.8), 3.78 (percentage score 75.5) and 3.76 (percentage score 75.2) respectively, they are also scored above average. The factors that are considered least are Price and convenience of service, their scores are 3.58 (percentage score 71.5) and 3.52 (percentage score 70.3), respectively on 5-point scale.

It is also showed that maximum of respondents agreed to the fact that advertisement does play a strong role in influencing the consumers in purchasing a product. Regarding the most popular media, most of the respondents i.e., 55\% have seen laptop advertisements in Newspapers, followed by television, which is being used by $51.7 \%$. $45 \%$ of respondents have seen laptop advertisements online, $32.5 \%$ have seen in various events like IT fair, Career fair, and trade fair. 30.8\% have seen laptop advertisements in magazines and below $10 \%$ of people have seen laptop advertisements in a movie theatre, billboards, and leaflets. None of the respondents have noticed laptop advertisements on the radio. The research also shows that friends and family highly influencing to buy a particular brand of laptop.

The study also showed that people are less price sensitive, people hardly switch from one brand of laptop to another because of price. In case of unavailability of their most preferred brand of laptop, most of them wait for their preferred brand and only a few buys second preferred brand or any available brand. Only higher price doesn't mean good quality to most of the costumers and they are also not comfortable in using the recent, not proven technology. Customers are also influenced by sales schemes and offer while purchasing laptop.

\section{RECOMMENDATIONS :}

Since portability is the main reason why people purchase laptops compared to desktops, companies should manufacture laptops as light as possible. The lighter laptops are, it is easier for users to carry.

The companies in order to retain or have loyal consumers towards the brand, it should try their best to avoid brand switching by their consumers. Companies should maintain a strong supply chain so that their product is available in the market.

Most of the laptop users are aged between 15-45 years. So, to make this group interested and involved, the laptop companies must bring out attractive and eye-catching promotions and advertisements. Consumers are also highly influenced by different schemes and offer so effective advertisement and promotion campaigns should be carried out to influence customers to buy a specific brand of laptop. 
Since for all consumer groups, core technical features and video quality is the most important attribute to prefer a brand, the companies ought to use latest technologies to continuously enhance these qualities to give maximum satisfaction to consumers.

People from different occupational backgrounds use laptops for different purposes so manufacturers should produce laptops with different configurations, i.e., depending on the need of the consumers.

Most people don't want to pay more than 1lakhs for laptops so manufactures should be able to sell their products within that range. Once a laptop is purchased people want it to use for at least 3 years so manufactures should make the product durable.

Dell laptop is popular among students, government employee and private working professional but business man prefers Apple computers. So Dell producer should develop strategies to attract businessman and Apple should develop marketing strategies to attract consumers from other occupational backgrounds like students, government, and private working professionals.

Customers are less price sensitive while purchasing laptops but the only high price doesn't mean good quality for customers. So, price should be balanced with features and quality of the laptop.

\section{REFERENCES :}

[1] Kotler, P., \& Keller, K. L. (2011). Marketing Management \& Interpretive Simulations Access Code Card Group B Package (14 ed.). Pearson Education.

[2] Sah, S., \& Mishra., A. K. (2020). Consumers' Brand Preference of Laptop in Kathmandu, Nepal. NOLEGEIN Journal of Consumer Behavior \& Market Research, 3(2), 7-23.

[3] Mishra. A. K., (2019). Influential Marketing Strategies Adopted by the Cement Industries. International Journal of Research-Granthaalayah, 7(10), 155-173.

[4] Mishra, A. K., Sharestha, B. (2019). Assessment of Consumer Influencing Factor in Decision Making for Selecting Cement Brands. South Asain Res J Bus Mgmt, 1(3), 91-105.

$$
\text { APROPAMPA, } 2011 \text { acceded from https://abcpd.com.br/wp- }
$$
content/uploads/2015/09/APRESENTA-O-IP-Carne-do-Pampa-Simposio-Ra-as-Nativas2015.pdf

[6] Pokhrel, L., Adhikari, D., \& Mishra, A.K. (2020). Adoption of Mobile Banking Among Users in Kathmandu Valley: Lens of Technological Acceptance Model. NOLEGEIN Journal of Management Information Systems, 3(2), 1-7.

[7] Heryanto, H. (2011). Effect of Marketing Strategy on Customer Loyalty Bajapuik Savings at PT. BPR Berok Gunung Pangilun Padang. International Journal of Lean Thinking, 2(1), 59-87.

[8] Kotler, P. (2013). Marketing Management: Analysis, Planning, Implementing and Control (1st ed.). India: Pearson Education.

[9] Kotler, P., \& Armstrong, G. (2010). Principles Of Marketing. India: Pearson Education.

[10] Kotler, P., \& Keller, K. L. (2011). Marketing Management \& Interpretive Simulations Access Code Card Group B Package (14 ed.). Pearson Education. 